ISSN: 0213-2087 e-ISSN: 2444-7080

DOI: https://doi.org/10.14201/shhcont38202099127

\title{
EMOCIONES VIRILES Y LA EXPERIENCIA DE LA NACIÓN IMPERIAL EN LAS GUERRAS DEL RIF (1909-1927)
}

\section{Manly emotions and the experience of the imperial nation in the Rif Wars (1909-1927)}

\author{
Gemma TORRES DELGADO \\ Universitat de Barcelona \\ gemmatorresdelgado@ub.edu
}

Recibido: 07/02/2020 Revisado: 04/07/2020 Aceptado: 10/07/2020

RESUMEN: Este artículo considera el proyecto del colonialismo español en Marruecos como fundamental en la construcción nacional de España entre finales del XIX y las primeras décadas del XX. Propone una aproximación al estudio de la nación desde abajo, que estudia la experiencia de los individuos y su vivencia de la nación, lejos de un análisis centrado solo en el Estado o las elites. Para ello, utiliza las herramientas de la historia de las emociones. Desde esta perspectiva y a través de la noción de comunidad emocional, analiza cómo vivían la nación imperial en el contexto africano diferentes sectores sociales e ideológicos que constituían comunidades emocionales distintas-dominantes o marginales. Quiere mostrar que esta vivencia emocional de la nación estaba profundamente marcada por el género y concretamente por las emociones ligadas a la masculinidad.

Palabras clave: nación; imperialismo; guerras del Rif; masculinidad; historia de las emociones.

ABSTRACT: This article claims the project of Spanish colonialism in Morocco as a key element in the national construction of Spain between the end of the 19th century and the first decades of the 20th. It aims is to study nation experiences from below, far from an analysis focused only on the state or the elites. To do so, it uses the tools of the history of emotions. From this perspective and through the notion of emotional community, it analyses how the imperial nation was experienced in the African context by different social and 
ideological sectors that constituted different emotional communities - dominant or marginal. It demonstrates that this emotional experience of the nation was deeply marked by gender and particularly by the emotions linked to masculinity.

Key words: nation; imperialism; Rif Wars; masculinity; history of emotions.

\section{LA NACIÓN EN ÁFRICA}

En los estudios recientes sobre el imperialismo se ha puesto de relieve la necesidad de considerar la interdependencia entre colonia y metrópoli en múltiples aspectos (el establecimiento de los límites de ciudadanía, la consecución del derecho a voto de las mujeres, la definición del concepto de raza). Entre ellos se ha señalado también la importancia del ámbito colonial en la configuración de la identidad nacional metropolitana ${ }^{1}$. La cultura imperial se convirtió en un elemento esencial de la cultura europea. En el periodo álgido de la expansión colonial, ningún europeo podía vivir al margen de esta realidad cultural ${ }^{2}$. Así la cosmovisión que implicaba el imaginario imperial era un elemento intrínseco en la definición de las identidades nacionales. La posesión de un imperio era un atributo fundamental de la nación, parte esencial de la definición de la propia comunidad imaginada, no una mera característica accidental ${ }^{3}$. Podemos considerar, por tanto, el proyecto del imperialismo español en Marruecos como fundamental en la construcción nacional de España entre finales del XIX y las primeras décadas del siglo XX. En el presente trabajo analizaremos cómo sus protagonistas disfrutaron o sufrieron este proyecto nacional y colonial, cómo los individuos experimentaron la nación imperial, cómo participaron de ella. Mostraremos cómo esta vivencia tuvo una dimensión de género fundamental.

A partir de 1909, un proyecto colonial que se había basado en la influencia comercial y diplomática se tornó en ocupación militar. La resistencia de los rifeños y la necesidad de España de mantener los compromisos internacionales, adquiridos con el

1. Hall, Catherine y Rose, Sonya: At Home with the Empire: Metropolitan Culture and the Imperial World. Cambridge: Cambridge University Press, 2006; ElEy, Geoff: «Imperial Imaginary, Colonial Effect: Writing the Colony and the Metropole Together». En: Hall, Catherine y Mcclelland, Keith (eds.): Race, Nation and Empire: Making Histories, 1750 to the Present. Manchester: Manchester University Press, 2010, pp. 217-236; SINHA, Mrinali: "Nations in an Imperial Crucible». En: Levine, Philippa: Gender and Empire. Oxford: Oxford University Press, 2004, pp. 181-202; Fradera, Josep. M: La nación imperial (1750-1918). Barcelona: Edhasa, 2015; Blanco, Alda: Cultura y conciencia imperial en la España del siglo XIX. València: Publicacions de la Universitat de València, 2012.

2. Eley, Geoff: op. cit., p. 227.

3. ARChilés, Ferran: “¿Ni imperio ni imperialismo? El imaginario nacional español y el imperialismo africanista en la España de la Restauración (c.1880-c.1909)». En: Archilés, Ferran, GARcía, Marta y SAZ, Ismael: Nación y nacionalización. Una perspectiva comparada. València: Publicacions de la Universitat de València, 2013, pp. 201-224. 
establecimiento del Protectorado en 1912, la obligaron a una guerra de conquista. En esta contienda sufrió derrotas importantes, que tuvieron un gran impacto en la opinión pública $^{4}$. Fueron la derrota del Barranco del Lobo (1909) y especialmente la derrota de Annual de 1921, en la que, después de días de sitio en los blocaos y aterrados por el ataque de los rifeños, los españoles huyeron desordenadamente. Tuvo como resultado numerosas víctimas. Muchos soldados y oficiales españoles cayeron prisioneros en manos de Abd-el-Krim. España no consiguió vencer a los rifeños hasta 1927 en una acción militar conjunta con Francia. Como un eco del 98, en torno a las derrotas en Marruecos la identidad de España se mostró especialmente inestable. Sus fracasos marroquíes fueron un tema de discusión candente. Así el contexto africano se convirtió en un escenario de discusión sobre la nación.

Diferentes discursos nacionales coexistieron en el escenario marroquí. Precisamente en estos años veinte, surgió en el ejército africano una nueva generación de militares especialmente conservadores, antiliberales y con una profunda desconfianza en la clase política. Se inspiraban en formas nacionalistas radicalizadas propias de las derechas revolucionarias europeas. En Marruecos fraguaron una cultura nacional específica definida en base a influencias diversas (tradicionalismo católico, tendencias vitalistas de influencia nietzscheana o el fascismo italiano). Una de ellas fue también la dimensión imperial de la identidad nacional ${ }^{5}$. Defensores de un cierto darwinismo social, creían que la expansión en Marruecos era necesaria para la supervivencia y la vitalidad de España. En África tenía la oportunidad de demostrar que no había perdido su tradición y fortaleza imperial. La antigua Castilla conquistadora y sus glorias en América eran su referente. La cuestión marroquí se convirtió en una ocasión excelente para la afirmación de un proyecto de regeneración nacional de cariz autoritario. Más allá del ejército africano, esta postura fue atractiva para los sectores más conservadores. Así la guerra en Marruecos ayudó a vestir este edificio ideológico conservador y nacionalista. Un nacionalismo militar de derechas que eclosionó en la sublevación contra la República 6 .

4. La Porte, Pablo: "Marruecos y la crisis de la Restauración (1917-1923)», Ayer, 63, 2006, pp. 51-74.

5. Varios autores han señalado la relevancia del periodo marroquí en la formación de la cultura de los militares que llevaron a cabo el golpe de Estado. Se han descrito las continuidades entre la cultura del ejército de África y el ejército del primer Franquismo. Algunos han calificado este periodo como prefascista. Véase: VISCARRI, Dionisio: Nacionalismo autoritario y Orientalismo: la narrativa prefascista de la guerra de Marruecos (1921-1927). Bologna: Il Capitello del Sole, 2004; Balfour, Sebastian: Abrazo mortal: de la guerra colonial a la Guerra Civil en España y Marruecos (1909-1939). Barcelona: Península, 2002; Gustau NERÍn: La guerra que vino de África. Barcelona: Crítica, 2005; JENSEN, Geoffrey: Irrational Triumph. Cultural Despair, Military Nationalism, and the Ideological Origins of Franco's Spain. Reno: University of Nevada Press, 2002; Macías, Daniel: «El africanismo del ejército franquista». En: Puell de la Villa, Fernando y Alda, Sonia (coords.): Fuerzas armadas y politicas de defensa durante el franquismo. Madrid: Instituto Universitario General Gutiérrez Mellado, 2010, id.: Franco "nació en África»: los africanistas y las Campañas de Marruecos. Madrid: Tecnos, 2019.

6. Balfour, Sebastian: op. cit. 
Este proyecto imperial convivía con otras retóricas nacionales en Marruecos. Por ejemplo, los sectores liberales, inspirados en la lógica de la misión civilizadora, defendían un proyecto colonial que reivindicaba España como nación moderna. No debía conquistar, sino llevar la civilización a Marruecos. Ahora bien, durante las guerras del Rif los sectores más reaccionarios fueron preponderantes. La retórica de la conquista más que la de civilización fue preeminente. Una oposición frontal a este proyecto colonial la sostuvieron los sectores anticoloniales que, desde el catalanismo, el socialismo o el anarquismo, se oponían al proyecto imperial y nacional del africanismo militar más conservador y apostaban por abandonar Marruecos.

En las páginas que siguen queremos estudiar cómo estos diferentes sectores sociales presentes en el Marruecos español vivieron de forma distinta la nación imperial. Lo analizaremos a través del género y especialmente mediante el análisis de emociones vinculadas a la virilidad. Para ello nos basaremos en el relato de la experiencia africana de altos mandos del ejército de África, pero también de soldados rasos obligados a servir en Marruecos y que tenían una clara postura anticolonial.

\section{NACIÓN Y EMOCIONES}

Entendemos la nación como una forma de identidad fluida, cambiante, codificada en relatos diversos que conviven en cada contexto histórico. Se construye, por tanto, mediante su discusión y continua redefinición. Se ha aceptado la idea del carácter narrativo de las identidades nacionales que no son fijas, sino fracturadas y móviles 7 . Ahora bien, como afirma Archilés, debemos interrogarnos también sobre su interiorización, en este sentido la noción de experiencia es clave ${ }^{8}$. Se ha criticado el concepto de nacionalismo banal de Billig, ya que concibe la nación como una losa sobre los sujetos, que aparecen como receptores pasivos. En cambio, los estudios enmarcados en el everyday nationalism proponen una aproximación al estudio de la nación que pone la atención en los individuos, activos en la construcción de la nación, que no se produce solamente desde el Estado o las elites, sino también desde abajo9. Así el concepto de banalidad del nacionalismo que Billig solo enuncia es desarrollado a través del estudio de la experiencia de lo cotidiano, por ejemplo, los espacios de la nación, la

7. Para esta caracterización de la nación véase: ARchilés, Ferran: «¿Quién necesita la nación débil? La débil nacionalización española y los historiadores». En: SABIO, Alberto (coord.): Usos de la historia y politicas de la memoria. Zaragoza: Prensas Universitarias de Zaragoza, 2004, pp. 187-208; id.: «Vivir la comunidad imaginada. Nacionalismo español e identidades en la España de la Restauración", Historia de la educación. Revista interuniversitaria, 27, 2008, pp. 57-85; id.: «Lenguajes de la nación. Las 'experiencias de nación y los procesos de nacionalización. Propuestas para un debate», Ayer, 90, 2013, pp. 91-114.

8. ARChilés, Ferran: "Lenguajes de la nación...", op. cit.

9. Ibid. 
ciudad o el barrio e incluso el espacio doméstico. Se define así un proceso en el que las narrativas producidas por el Estado conviven con las prácticas producidas por los sujetos desde abajo, en una interacción a través de la cual se reproduce cotidianamente la nación ${ }^{10}$. Algunos autores nos hablan de procesos de "personalización» de la nación, que se producirían a través de diferentes mecanismos, por ejemplo, la percepción personal del paisaje nacional o el reconocimiento de símbolos patrios. Así se estudia cómo la nación se inserta en la identidad de los individuos ${ }^{11}$.

En el presente trabajo consideramos que una forma especialmente eficaz de estudiar este proceso de vivencia de la nación se encuentra en la historia de las emociones. Diversos autores han señalado la importancia del cuerpo y las emociones en la aproximación a los fenómenos históricos. Esta perspectiva parte del reconocimiento de ciertas limitaciones del giro lingüístico, que amenaza con una interpretación en la que el sujeto quede excesivamente determinado y atrapado en el lenguaje ${ }^{12}$. Las emociones se conciben como un diagnóstico de la realidad que se aloja en el cuerpo, se valoran como forma de acceso al mundo y deben tenerse en cuenta en el estudio del pasado ${ }^{13}$. Son un tipo de evento y las podemos considerar fenómenos históricos ${ }^{14}$. Es decisivo además identificar su carácter performativo, ya que tienen una capacidad creativa ${ }^{15}$. Así las emociones nos acercan a las vivencias de los sujetos y son un elemento esencial en la comprensión de las formas de reproducción de la nación desde abajo.

Autores como Reddy o Rosenwein han definido las herramientas básicas de la historia de las emociones. En su definición de emoción, Reddy parte de un complejo análisis del sujeto como desagregado y de teorías tanto cognitivas como antropológicas para concluir que las emociones no son un puente entre el cuerpo y la mente, ni algo radicalmente distinto del pensamiento o la razón sino "goal-relevant activations of thought material» ${ }^{16}$. Es decir, las emociones están relacionadas con una gran variedad de pensamientos e ideas que cada situación genera para el sujeto. A través de un complejo proceso, que Reddy llama traducción, se enuncian y en ese momento

10. Ibid., p. 103. Véase también, Quiroga, Alejandro, ARCHILÉs, Ferran: Ondear la nación. Nacionalismo banal en España. Granada: Comares, 2018.

11. Quiroga, Alejandro: "La nacionalización en España. Una propuesta teórica», Ayer, 90, 2013, pp. 17-38; Molina Aparicio, Fernando: "La nación desde abajo. Nacionalizaicón, individuo e identidad nacional», Ayer, 90, 2013, pp. 39-63; HeArn, Jonathan: "National identity: banal, personal and embedded", Nations and nationalism, 13 (4), 2007, pp. 657-674.

12. Díaz Freire, Javier: "Emociones e Historia. Presentación», Ayer, 98, pp. 13-20, 2015; Moscoso, Javier: "Politics of Pain: "A Good Subject for Eminent Amateurs", Rúbrica Contemporanea, 4 (7), 2001.

13. Díaz Freire, Javier: op. cit.

14. Díaz Freire, Javier: op. cit.; Moscoso, Javier: "Polítics of pain...» op. cit.

15. OBrador, Pau: «Being-on-holiday. Tourist dwelling, bodies and place», Tourist Studies, 3 (1), 2003, pp. 47-66.

16. "Activación de pensamientos relacionados con objetivos relevantes". (Todas las traducciones son de la autora). REDDY, William: The Navigation of Feeling. Cambridge: Cambridge University Press, 2001, p. 128. 
se acaban de definir y de vivir las emociones. El autor denomina estas declaraciones emocionales emotives. Deben entenderse como un acto de habla que no es un reflejo lingüístico de lo sentido, sino que tiene una dimensión creativa y autoexploratoria. En el momento en que se enuncia, la emoción puede confirmarse o desmentirse, ganar o perder intensidad ${ }^{17}$. Estas enunciaciones emocionales tienen una tercera dimensión: la relacional. Es decir, dependen del contexto y están vinculadas con los objetivos, relaciones y valores del sujeto y su contexto. Además, los emotives son performativos, hacen cosas en el mundo ${ }^{18}$.

En un sentido similar Rosenwein define las emociones como «assesments based on experience and goals, the norms of the individual's social context provide the framework in which such evaluations take place and derive their meaning» ${ }^{19}$. Del mismo modo que Reddy, Rosenwein señala que las emociones implican un juicio sobre si determinada circunstancia es positiva o negativa para el sujeto, estas valoraciones dependen de los valores sociales en cada contexto ${ }^{20}$. Las emociones no desbordan sin control al sujeto como el agua, sino que son "the products of experience, and experience itself is shaped by the practices and norms of a person's household, neighborhood, and larger society” ${ }^{21}$. Así las emociones son consideradas fenómenos sociales que dependen de la cultura y las narrativas que las personas usan para dar sentido a las situaciones que las provocan y sobre los modos idiosincráticos y convencionales que usan para expresarlas $^{22}$. Para Rosenwein, como para Reddy, emociones y pensamientos no pueden distinguirse claramente. Los individuos se educan en emociones que se basan en sus creencias. Al mismo tiempo, las emociones ayudan a crear, validar y mantener estas creencias $^{23}$. Rosenwein puso énfasis, además, en la importancia de la expresión gestual y no verbal de las emociones en el cuerpo, en manifestaciones como el sonrojo o las lágrimas. Como afirma Arbaiza «toda emoción en su dimensión afectiva o sensorial queda inscrita en el cuerpo [...] emoción y sensación corporal son partes indisociables y constitutivas del conocimiento del mundon ${ }^{24}$.

17. ReDDY, William: op. cit., p. 102.

18. REDDY, William: op. cit., p. 105.

19. «Las valoraciones basadas en experiencias, objetivos, normas propias del contexto del individuo aportan el marco en el que estas evaluaciones se producen y de las que dervia su significadon. RosEnwEIn, Barbara H: Emotional Communities in The Midle Ages. New York: Cornell University Press, 2007, p. 15.

20. Rosenwein, Barbara H: op. cit., p. 191.

21. «El resultado de la experiencia, y la experiencia en sí misma, está formada por las prácticas y normas de la familia, el vecindario y la sociedad en su conjunto». REDDY, William: op. cit., p. 15.

22. PAMPLER, Jan: «The history of emotions: an interview with William Reddy, Barbara Rosenwein and Peter Stearns", History and Theory, 49, 2010, 237-265, p. 259.

23. Rosenwein, Barbara H: op. cit., p. 196.

24. Arbaiza, Mercedes: «Sentir el cuerpo»: subjetividad y política en la sociedad de masas en España (1890-1936)", Política y Sociedad, 55,1, 2018, pp. 71-92, p. 80. 
Las herramientas de la historia de las emociones así definidas nos son de enorme utilidad para analizar la experiencia de los individuos ante un fenómeno social como la nación, ya que relacionan una vivencia íntima con su dimensión social. Al mismo tiempo, el carácter autoexploratorio, creativo y performativo de las emociones - y no simplemente representativo- nos permiten analizar tanto la conformación de la comunidad emocional del africanismo reaccionario, como la experiencia emocional alternativa de aquellos sectores que cuestionaron la nación imperial.

Para explicar esta dimensión social de los fenómenos emocionales, Reddy ha acuñado la noción de régimen emocional, que se define como «the set of normative emotions and the official rituals, practices and emotives that express and inculcate them; a necessary underpinning of any stable political regime» ${ }^{25}$. Así en su análisis empírico, el autor define la naturaleza de diferentes regímenes emocionales, como por ejemplo el correspondiente a la Francia revolucionaria o el de la postrevolucionaria, valorando el nivel de libertad emocional o sufrimiento que caracterizaba a cada uno de ellos. La discusión sobre la excesiva rigidez y amplitud del término régimen emocional, que en la definición de Reddy parece ser omnipresente y absoluto en determinado contexto histórico ${ }^{26}$, llevó a Barbara Rosenwein a formular la noción de comunidad emocional. Coincidentes con las comunidades sociales — como la familia, el barrio, el monasterio, la parroquia - las definió como "groups in which people adhere to the same norms of emotional expression and value - or devalue - the same or related emotions ${ }^{27}$. Las comunidades emocionales constituyen «systems of feeling: what these communities (and the individuals within them) define and assess as valuable and harmulf to them: the evaluation that they make about other's emotions; the nature of the affective bonds between people that they recognize; and the modes of emotional expression that they expect, encourage, tolerate and deplore ${ }^{28}$. Más que una sola comunidad o régimen emocional coexisten diversas comunidades simultáneamente. Si como hemos repetido las emociones se relacionan con valoraciones de lo que es positivo o dañino para el individuo, cada situación puede tener múltiples respuestas emocionales. La noción de comunidades emocionales múltiples nos ayuda a comprender qué respuesta prevalece y cuales se descartan ${ }^{29}$, ya que no todas las comunidades emocionales están al mismo

25. «El conjunto de emociones normativas y los rituales oficiales, las prácticas, los emotives que las expresan y las inculcan, la base necesaria de cualquier régimen político estable». RedDy, William: op. cit., p. 129.

26. PAmpler, Jan: op. cit., p. 256.

27. "Grupos en los que el individuo se adhiere a las mismas normas de expresión emocional, valora o menosprecia las mismas emociones o emociones similares». RosenweIn, Barbara H: op. cit., p. 2

28. «Sistemas de emociones: lo que estas comunidades (y los individuos dentro de ellas) definen y evalúan como valioso o dañino para ellos: la evaluación que hacen sobre las emociones de los demás; la naturaleza de los lazos afectivos entre individuos que reconocen; y los modos de expresión emocional que esperan, alientan, toleran y deploran». PAmpler, Jan: op. cit., p. 252.

29. Rosenwein, Barbara H.: op. cit., p. 199. 
nivel, algunas son preponderantes, otras subordinadas. En efecto, los grupos en el poder, al dominar los instrumentos de comunicación, tienen una poderosa influencia en las normas emocionales de un periodo y lugar determinado. Ahora bien, la existencia misma de comunidades emocionales marginales implica que la contestación también existe $^{30}$. Así la noción de comunidades emocionales nos servirá para analizar la diversidad de experiencias de la nación que convivían en nuestro contexto. Algunas de ellas se conformaron en una comunidad emocional preponderante que definió un sistema de emociones concreto para la vivencia de la nación. Otras experiencias cristalizaron en una comunidad emocional subordinada o marginal que contestaba este repertorio emocional como forma de participar de la nación.

Por tanto, la dimensión social de las emociones ha sido ampliamente descrita ${ }^{31}$, así como su carácter performativo ${ }^{32}$. "La Historia Cultural de las Emociones no puede consistir entonces en saber cómo podríamos acceder a los contenidos privados de la conciencia de otra persona, sino en saber cómo se construye una experiencia articulada ${ }^{33}$. Según estas definiciones, las emociones son decisivas en el análisis del surgimiento de subjetividades políticas, ya que su expresión cobra sentido «dentro de una valoración o forma de conocimiento de tipo moral, sobre lo bueno y lo malo. Por eso las emociones son compartidas y aprendidas socialmente y son profundamente políticas» ${ }^{34}$. En nuestro caso, la consolidación de un sujeto político como el africanismo reaccionario tuvo una clara dimensión emocional, así como como su contestación por parte de los sectores anticoloniales.

Diversos autores han señalado la importancia de las emociones en el estudio de la nación y el nacionalismo ${ }^{35}$. Como señala Banti en su análisis de la retórica patriótica italiana, la nación no solo se reproduce a través de imágenes, ideas o discursos. Se construye también a través de una educación de las emociones que favorecen la adhesión de los individuos a la patria. Por ejemplo, se define el amor a la nación como

30. Ibid, p. 200.

31. Delgado, Luisa Elena; Fernández, Pura, Labanyi, Jo: "Cartografía de las emociones en la cultura española contemporánea: teorías, prácticas y contextos culturales». En: Delgado, Luisa Elena; Fernández, Pura, LABANYI, Jo: La cultura de las emociones y las emociones en la cultura española contemporánea (siglos XVIII-XXI). Madrid: Cátedra, 2018.

32. Moscoso, Javier: "De la Historia de las Emociones a la Historia de la Experiencia. Los dibujos y las notas de un marino español durante la Guerra Civil». En Delgado, Luisa Elena; Fernández, Pura, Labanyi, Jo: En: Delgado, Luisa Elena; Fernández, Pura, Labanyi, Jo: La cultura de las emociones y las emociones en la cultura española contemporánea (siglos XVIII-XXI). Madrid: Cátedra, 2018, p. 218.

33. Ibid, p. 231

34. Arbaiza, Mercedes: op. cit., p. 81

35. BANTI, Alberto Mario: Sublime madre nostra. La nazione italiana dal Risorgimento al fascismo. Bari: Laterza, 2011; SLugA, Glenda: "Passions, patriotism and nationalism, and Germaine de Staël», Nations and Nationalism, 15 (2), 2009, pp. 299-318. 
el que se siente por una madre o el dolor por la muerte de un hijo por la patria como algo digno y positivo. Asimismo, se ha estudiado en diversos contextos cómo los funerales por los caídos en la guerra son un proceso muy importante en la incorporación emocional de la nación, ya que conectan la emoción individual con el sentimiento colectivo de todos los que han perdido a alguien cercano en la guerra y la dotan de sentido nacional ${ }^{36}$. En esta misma línea, Hoeagerat ha descrito por ejemplo cómo en la escuela se enseña a los niños y niñas el vocabulario normativo de amor a la patria a través de excursiones y prácticas corporales — comer, cantar, caminar por determinados lugares-, de manera que se entrenan y se practican con el cuerpo los afectos que los atarán de adultos a una entidad abstracta como es la nación ${ }^{37}$

Para comprender este proceso de vivencia de la nación a través de las emociones debemos tener en cuenta también su dimensión de género, ya que la experiencia de la nación no se da de forma aislada, sino en conjunción con otras identidades religiosa, de clase o de género ${ }^{38}$. Como han descrito Sluga, Banti o Rosenwein, las emociones nacionales, sus expresiones y metáforas tienen una clara connotación de género ${ }^{39}$. Existe una amplia literatura sobre la relación entre género y nación. Describe por ejemplo cómo se asignan diferentes tareas patrióticas a hombres y mujeres, cómo la nación se encarna en imágenes femeninas y también masculinas o cómo los discursos nacionalistas prescriben determinados modelos de feminidad y masculinidad como propios de la nación y censuran otros como lesivos para la patria ${ }^{40}$. Asimismo, Nagel ha descrito como nación, masculinidad e imperio se configuran mutuamente en el periodo contemporáneo, parecen «hechos con el mismo molde» ${ }^{41}$. En otro lugar hemos estudiado, a través del análisis del discurso y la representación, cómo en el contexto colonial marroquí la masculinidad era un elemento decisivo en la construcción de

36. CÂRSTOCEA, Raul: "Bringing Out the Dead: Mass Funerals, Cult of Death and the Emotional Dimension of Nationhood in the Case of the Legionary Movement in Interwar Romania", Workshop 3. Emotions and everyday nationhood in European history (19th-20th century), 31 May - 1 June 2017. Venue: LudwigMaximilians-University Munich, Germany.

37. Hoegaerts, Josephine: "Learning to Love. Embodied Practices of Patriotism in the Nineteenth-Century Classroom (and Beyond)", Workshop 3. Emotions and everyday nationhood in European history (19th-20th century), 31 May - 1 June 2017. Venue: Ludwig-Maximilians-University Munich, Germany.

38. Mrinali SinHA: "Nations in an Imperial...» op. cit.

39. PAMPler, Jan: op. cit., p. 254; Banti, Alberto Mario: Sublime madre... op. cit.; SLugA, Glenda: «Passions, patriotism..." op. cit; Bolufer, Mónica: "Afectos razonables: equilibrios de la sensibilidad dieciochesca». En: Delgado, Luisa Elena; Fernández, Pura, LABAnYi, Jo: La cultura de las emociones y las emociones en la cultura española contemporánea (siglos XVIII-XXI). Madrid: Cátedra, 2018, p. 226.

40. Andreu Miralles, Xavier: "El género de las naciones. Un balance y cuatro propuestas", Ayer, 106, 2017, pp. 21-46, Yuval Davis, Nira: Gender and nation. London: Sage Publications, 1997.

41. NAGEL, Joane: "Masculinity and Nationalism: Gender and Sexuality in the Making of Nation». Ethnic and Racial Studies, 2(2), 1998; Id.: "The Nation». En: Kimmel, Michael; Connell, Raewyn; Eran, John: Handbook of studies on Men and Masculinities. Thousand Oak: Sage Publications, 2005. 
la nación, que se encarnaba en imágenes y valores viriles ${ }^{42}$. En el presente trabajo queremos estudiar esta íntima relación entre género y nación en otro aspecto, en su dimensión emocional.

Desde esta perspectiva y a través de la noción de comunidades emocionales, analizaremos cómo vivían la nación imperial, en nuestro contexto africano, diferentes sectores sociales, que constituían comunidades emocionales distintas — dominantes o marginales. Mostraremos que esta vivencia emocional de la nación estaba profundamente marcada por el género y concretamente por las emociones ligadas a la masculinidad.

\section{EMOCIONES VIRILES PARA LA VIVENCIA DE LA NACIÓN IMPERIAL}

Los militares africanistas, representantes del proyecto imperial y nacional reaccionario que hemos descrito, se constituyeron en Marruecos en un grupo cohesionado con una identidad propia opuesta a la supuesta debilidad de los políticos y militares metropolitanos. Se consideraban como los verdaderos defensores de los intereses nacionales, los únicos capaces de salvar España. Este grupo compartió una misma cosmovisión sobre el proyecto colonial y nacional en Marruecos y un mismo sentido de misión (que terminaría en la sublevación contra la República) y también, como explicaremos a continuación, una misma comunidad emocional.

Destacados representantes de este sector ideológico participaron en el debate nacional que suscitó el llamado "problema de Marruecos", causado por las derrotas en el Rif. Escritores, militares y periodistas reflexionaron sobre lo ocurrido en estas guerras, especialmente después de Annual, y analizaron las causas de las derrotas, lo que se convirtió en el fondo en una reflexión sobre la naturaleza de la nación española. Es el caso de personajes tan destacados como Francisco Franco, que relató su experiencia en Marruecos en Diario de una bandera, o de miembros relevantes del ejército como Queipo de Llano o escritores vinculados a este sector ideológico como Luys Santa Marina, que escribió Tras el Águila del César en honor a la Legión o Giménez Caballero, que plasmó su reflexión sobre la guerra en el Rif en Notas marruecas de un soldado. Este pensamiento se expresó también a través de la prensa o las novelas por entregas, muy populares en el periodo, especialmente las de temática marroquí. En todas estas obras se describen las vivencias de estos militares en África y vemos a través de ellas cómo se conformaba su adhesión emocional a la nación imperial ${ }^{43}$.

42. Torres Delgado, Gemma: «La nación viril. Imágenes masculinas de España en el africanismo reaccionario", Ayer, 106, 2017, pp. 133-158; id.: "La reivindicación de la España civilizada: masculinidad española en el discurso colonial sobre Marruecos (1900-1927)", Cuadernos de Historia Contemporánea, 39, 2017, pp. 59-81, id.: La virilitat d'Espanya a l'Àfrica. Nació i masculinitat al colonialisme al Marroc. Catarroja: Editorial Afers, 2020.

43. Fernández, Delgado y Labanyi han demostrado la «importancia de la literatura de masas para la comprensión de la "estructura de sentimiento» de una determinada época histórica», véase: DELGADo, Luisa Elena; Fernández, Pura, Labanyi, Jo: “Cartografía de las...», op. cit., p. 14. 
La protagonista de la novela popular No quiere morir de Antonio Cases enuncia ante el fracaso de las operaciones en Marruecos: «Si la razón nacional permanecía callada, ¿por qué no vibraban los instintos, los sentimientos, las afecciones? ”44. Elvira, una mujer que en la novela encarna España y aparece como una especie de heroína de la patria, reclama una adecuada educación emocional de sus conciudadanos para que la situación en África se enfrente de forma resuelta y se rectifiquen los errores cometidos. La actitud emocional de los españoles respecto al problema marroquí, es decir respecto a la nación, debe cambiar. Este es uno de los principales propósitos de esta novela popular, publicada en 1924 y que narra cómo son recibidas las noticias sobre la guerra del Rif en un pueblo de Castilla. Como enuncia su protagonista: «el corazón nuestro [de los españoles] espera quien lo sepa descubrir», este no es otro que un militar resuelto lleno de heroísmo "para quién solo exista la patria", un militar que sepa infundir en los españoles un adecuado amor a España ${ }^{45}$. En este y en el resto de los autores cercanos al africanismo militar podemos identificar una comunidad que comparte y prescribe una determinada relación emocional de los sujetos con la nación, que podemos leer en las obras más oficialistas y elevadas, pero también en las más populares.

En primer lugar, la humillación y dolor patrio caracterizan la vivencia de las severas derrotas marroquíes. Este dolor aparece como una de las emociones principales a través de la cual los sujetos se vinculan con la nación. Así lo relata Franco, ante las noticias que llegan de Melilla que anuncian la derrota de Silvestre —el general al mando- y su suicidio, "Sentimos en nuestros corazones la presión del dolor patrio» ${ }^{46}$. El mismo dolor de patria que se expresa en la prensa de Melilla, la ciudad «siente como las demás ciudades todas los dolores y amarguras de la patria, pero aquellos que se derivan de la guerra los siente con más intensidad ${ }^{47}$. Para Giménez Caballero la situación de España produce vergüenza. Al volver la mirada hacia el propio uniforme, el español «Siente como un deseo de llorar" ${ }^{48}$. Vergüenza por la derrota ante un pueblo, el rifeño, supuestamente inferior, pero sobre todo frente al resto de naciones europeas ante las cuales España se siente impotente ${ }^{49}$. La máxima expresión de esta humillación nacional se produce cuando el caudillo rifeño, Abd-el-Krim, pasea por Tetuán con el fajín del general español vencido, Silvestre, en su chilaba ${ }^{50}$.

44. CASES, Antonio: No quiere morir (novela heroica). Madrid: Imprenta de Félix Moliner, 1924, p. 177.

45. Ibid., p. 185.

46. Franco, Francisco: Diario de una bandera. Madrid: Doncel, 1921 [1976], p. 95.

47. "Al pueblo español", Telegrama del Rif, 26 de agosto de 1923, p. 3.

48. Giménez Caballero, Ernesto: Notas marruecas de un soldado. Barcelona: Planeta, 1983 [1923].

49. Giménez Caballero, Ernesto: op. cit.; Telegrama del Rif, 26 de agosto de 1923, p. 3.

50. "Sobre la muerte del general Silvestre», La Vanguardia, 10 de agosto de 1921. La emoción de humillación ha sido descrita ampliamente en la historia de las emociones. Véase, por ejemplo, REDDY, William: op. cit., pp. 215 y siguientes. 
Las anécdotas que reproducen este sentimiento de vejación se suceden en los relatos periodísticos del desastre, pero también en la ficción. Se refieren a la nación en su conjunto y también a las experiencias de los hombres concretos. Los soldados, cabizbajos, humillados por el hecho de haberse rendido, no quieren ser entrevistados ni salir en las fotografías ${ }^{51}$, así lo relata el periodista del $A B C$, Zegri. Del mismo modo lo vive el general Navarro, cautivo de los rifeños. Se siente tan humillado por la derrota y su situación de cautiverio que se niega a ver a nadie, ni a su propia hija, como relata Luys de Oteyza en Abdlkrim y los prisioneros ${ }^{52}$. Las condiciones en las que se encuentran estos cautivos de Abd-el-Krim evidencian este sentimiento: «a un general lo llegaron a amarrar con cadenas al cuello para tenerlo inmóvil y vencida la cerviz, como a un buey insumiso y joven”³. Así lo relata la novela No quiere morir que, como buen producto de educación emocional, reprende en su moraleja final al soldado cobarde que ha preferido conservar la vida que entregarla a la patria. La vida en la humillación no vale la pena ${ }^{54}$.

Este dolor no se refiere en ningún caso al sufrimiento por la muerte de los hombres concretos ni tiene que ver con el duelo por los familiares, amigos o compañeros perdidos. De hecho, el dolor por las muertes personales está duramente censurado. Franco en su obra Diario de una bandera apenas expresa tristeza por la muerte de su fiel ayudante simplemente da escueta noticia de ello. Se reprende a aquellos conciudadanos que lamentan las excesivas muertes que se están produciendo en Marruecos. Así se expresa en un significativo artículo en el Diario $A B C$ en el que se censura el "histerismo" que domina el discurso público sobre Marruecos. El país debe comportarse de forma más «Viril», lo cual significa tener calma y no sufrir por los muertos en el Rif ${ }^{55}$. Así en esta comunidad emocional se prescriben determinadas emociones nacionales, pero también se reprueban otras en un proceso complejo de educación emocional para la patria.

Las consecuencias de este sentimiento de humillación para la nación son nefastas: produce "tristeza», «aletargamiento», pérdida de iniciativa. Lo que debió ser un revés, según Franco, fue un desastre "por crisis de ideales»y "virtudes aletargadas» ${ }^{56}$. Del mismo modo Queipo de Llano considera que la esterilidad de los políticos e intelectuales, que quieren evitar más muertes y dispendios económicos en Marruecos, produce abatimiento en el espíritu, «fatalismo musulmán»57. Una emoción duramente censurada en la experiencia de la nación. Es más, la empresa africana debe culminarse, ya que

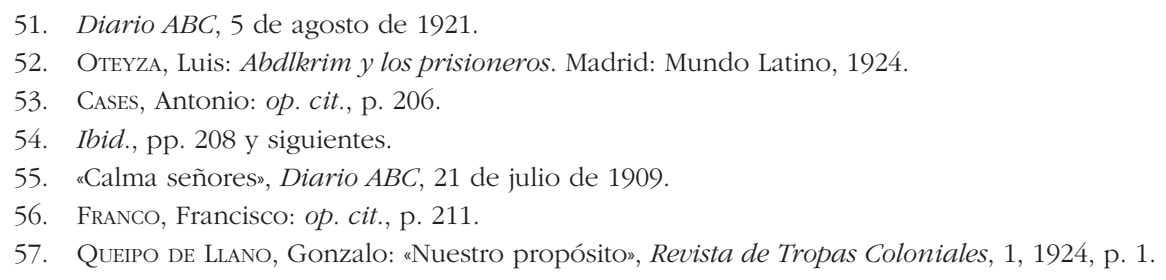


abandonar África significaría la "depresión del espíritu nacional»" ${ }^{58}$. Así una correcta relación emocional con la nación implica la censura del dolor por los muertos y la tristeza o el abatimiento por las derrotas.

Otra de las emociones a través de las cuales se vehicula la relación de los sujetos con la nación es el odio al otro, que se instiga como sentimiento nacional. Odio al enemigo rifeño, con el cual los españoles se ceban hasta la máxima crueldad, en las descripciones de la guerra de Luys Santa Marina, pero también y especialmente odio a los rivales europeos, en particular los franceses ${ }^{59}$. La combinación del sentimiento de humillación y odio al otro se resuelve en el deseo de venganza, que es un elemento muy presente en la retórica emocional de estas obras. Una emoción imprescindible para superar los sentimientos de dolor y humillación tan censurados y recobrar por fin la dignidad nacional.

Así en esta literatura se describe una comunidad emocional, la del africanismo reaccionario, que se caracteriza por una relación dolorosa con la nación cuyo motivo es la dignidad de la patria. Se concreta en emociones como la humillación, la vergüenza, el deseo de venganza y la censura de la depresión y el abatimiento o el duelo por las muertes. Todas estas emociones dependen de una compleja evaluación del significado de estas derrotas para la patria, que debe ser fuerte, siempre vencedora y que se juega su prestigio en sus éxitos en la arena internacional. Así al mismo tiempo que se enuncian estas emociones de humillación y vergüenza se performa y se vive la nación imperial.

Ahora bien, otros sentimientos de carácter más positivo caracterizan la relación emocional de los sujetos con la patria. Franco describe, en su relato, a los soldados de la legión como los encargados de la salvación de España y de la regeneración nacional. Así proclama que solo reconociendo los méritos y las cualidades de los soldados de África "habremos hecho Patria" ". Si lo analizamos detenidamente comprobaremos que la patria se "hace» a través de emociones muy concretas. Una de las principales es la alegría, que debe ser la principal emoción de los soldados que van a luchar. La guerra se vive con alegre disposición en el relato de Franco, el ambiente de campaña es de celebración. Han caminado muchos kilómetros, pero la proximidad del campo de batalla hace que los soldados estén «entusiasmados, cantan y los vivas a España se pierden al alejarse el barco hacia Melilla ${ }^{61}$. En el relato de Luys Santa Marina el día a día de los hombres en campaña se caracteriza por la camaradería, las canciones y

58. Unamuno, Miguel de: "Me preguntan qué es lo que pienso de nuestro problema en África", Nuevo Mundo, 17 de julio de 1913.

59. SAnta Marina, Luys: Tras el águila del César: elegía del Tercio, 1921-1922. Barcelona: Planeta, 1980 [1924].

60. Franco, Francisco: op. cit., p. 80.

61. Ibid., p. 95. 
el buen ánimo ${ }^{62}$. Esta retórica es muy común en las descripciones de la guerra y la batalla. Se describe la llegada de los soldados al campamento, animosos. Se elogia a los jóvenes que van a batirse por primera vez, son «momentos de intensa emoción» 63 .

Preciamente la exaltación emocional, el ánimo convulso, en palabras del general Burguete, es otra de las características propias de este disposición de ánimo necesaria para vivir la nación ${ }^{64}$. De hecho se admira «el esqueleto de las pasiones» del rifeño, «impulsivas y bárbaras» ${ }^{65}$. El ímpetu que acompaña esta forma de enardecimiento emocional es fundamental para un elemento central en la vivencia de la nación: el sacrificio. Esta especie de estado anímico alterado es necesario para el servicio a la patria, así lo prescribe un padre a un hijo, que escribe en una carta en el periódico «ese juramento que hiciste a la bandera hasta derramar la última gota de sangre hay que cumplirlo como tu padre y tu abuelo han sabido cumplirlo; así es que te encargo mucho valor y corazón» ${ }^{66}$. No solo le reclama valor para el sacrificio patrio, sino algo más: también pasión y emoción, «corazón». En efecto la patria reclama una exaltación vibrante y ardiente que todo lo reforme. Busquemos entre todos al campesino o al militar que magnífico y dominante haga caminar a España por las rutas gloriosas de nuestra grandeza " ${ }^{67}$. Lo mismo pide Unamuno que explica que en España, en algunos momentos, las llamadas al patriotismo consiguen «electrizar al pueblo», pero todavía de forma insuficiente ${ }^{68}$. Así se elogía esta excitación, esta electricidad como emoción patriótica. La protagonista de la novela de Cases lo expresa a través de una metáfora muy habitual en la descripción de las emociones, la que las compara con el agua espontánea e incontrolable: «su alma era un surtidor por el que surgía, en impulso recto, el agua fecunda de su fe» y su «entusiasmo patriótico» ${ }^{69}$. Este enardecimiento emocional hace placentera la vivencia de la nación y el sacrificio por ella ${ }^{70}$.

Esta alegría se torna a veces en una especie de placer de la violencia. Es explícito en la obra de Luys Santa Marina. Es la legión quien encarna esta emoción nacional particular. Los legionarios son furia de España, fuente de destrucción y victoria: "Nada quedaba oculto, e implacables / picos y garras para herir dispuestos, / todo lo deshacían: sólo restos / dejaron en los campos miserables / hombres halcones de orgullosos ojos / eran los legionarios ${ }^{71}$.

62. SANTA Marina, Luys: op. cit., pp. 114-115.

63. Corrochano: "Glorificación de Abdlkrim", Diario ABC, 11 de agosto de 1922.

64. Burguete: "El hombre y la guerra", La correspondencia militar, 17 de agosto de 1911.

65. Giménez Caballero, Ernesto: op. cit., p. 17.

66. "El bautizo de sangre». Diario ABC, 11 de agost de 1921, p. 7.

67. Cases, Antonio: op. cit., p. 72.

68. Unamuno, Miguel de: op. cit.

69. Cases, Antonio: op. cit., p. 97.

70. El enardecimiento emocional ha sido descrito como emoción recurrentemente en los esudios sobre historia de las emociones. Véase, por ejemplo, Rosenwein, Barbara. H: op. cit. 149.

71. SAnTA Marina, Luys: op. cit., p. 25. 
Los legionarios cantan y matan, matan y cantan alegres ${ }^{72}$. El asesinato y la tortura al enemigo son descritos como una fiesta, como un «baile de máscaras» ${ }^{73}$. Los legionarios no tiemblan ante la muerte, al contrario, sonríen ${ }^{74}$.

Este goce de la violencia se relaciona con otro sentimiento patrio, el último componente que queremos destacar de esta comunidad emocional del africanismo reaccionario: el placer de la dominación, del ejercicio del poder. Esta emoción recorre toda la obra de Santa Marina, también la expresa la protagonista de No quiere morir: "Cuando Elvira se asoma al ventanal [...] siente nacer en su pecho castellano los afanes de grandeza y de dominio que hicieron inmortal una raza ${ }^{75}$. Este afán se torna en soberbia, en orgullo de la victoria. Todos ellos sentimientos fundamentales en la vivencia patria. Precisamente después de la derrota es necesario recuperar el honor perdido, levantar el espíritu nacional, que lo vale todo, incluso exponer la vida de los soldados. Porque el orgullo de España es fundamental para la vivencia de la nación ${ }^{76}$. Se considera que cada español en África lleva la dignidad de toda la nación. Así los sujetos experimentan en propia piel los sentimientos de orgullo y honor que derivan del ejercicio del poder y la autoridad. Así estos sentimientos nacionales se convierten también en una experiencia individual.

Como hemos indicado al inicio, en diferentes contextos se ha descrito cómo las experiencias emocionales de la nación se expresan a través de los lazos familiares. En estas obras también aparecen estas referencias que están tan consolidadas en las retóricas nacionales. Por ejemplo, se hace mención al amor a España como el amor a una madre, que debe ser sincero, sin intereses ${ }^{77}$. Ahora bien, aunque estas apelaciones están presentes, en los relatos analizados predominan otro tipo de emociones como las descritas en la vivencia emocional de la nación imperial: la alegría, el enardecimiento, el orgullo en la defensa de la victoria, el placer de la dominación o el goce de la violencia. Estas emociones performan y permiten experimentar determinados valores nacionales como el sacrificio patrio como algo superior a la propia vida o la necesidad de toda nación de vencer, dominar y no ser subyugada.

En efecto, como hemos reiterado las emociones están relacionadas con la evaluación de las situaciones vividas según los valores predominantes en cada contexto. Entre los elementos contextuales que se relacionan con las emociones descritas, los valores de género son especialmente relevantes. Es evidente que esta retórica nacional y emocional no es neutra a nivel de género. No podemos entender este proceso de

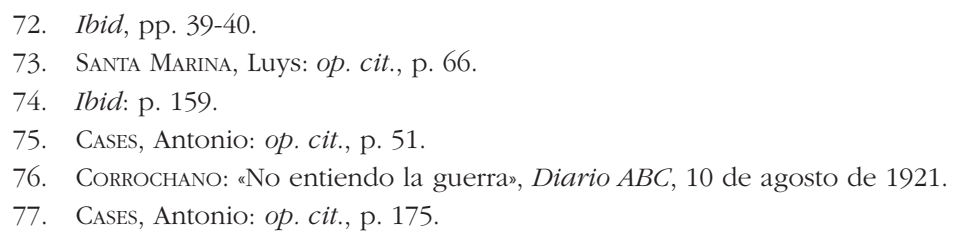


vivencia de la nación si no lo vinculamos a otra experiencia íntima, la vivencia de la masculinidad, en concreto del modelo de masculinidad hegemónico en este contexto: el soldado ${ }^{78}$. Precisamente este periodo, las primeras décadas del siglo XX y hasta los años treinta, es un momento convulso en la definición de las identidades de género en toda Europa y también en España ${ }^{79}$. Los ideales heredados del pasado empiezan a tambalearse. Tanto en el ámbito femenino como en el masculino aparecen modelos ambiguos en la definición de su identidad de género (la mujer moderna, el dandy o el homosexual) ${ }^{80}$. La masculinidad aparece como una categoría inestable. Debe demostrarse continuamente, siempre en duda de ser perdida o no suficientemente acabada ${ }^{81}$. Se teme la indiferenciación sexual. Especialmente desde los sectores conservadores, se quiere afirmar la máxima virilidad a través del heroísmo militar y contrarrestar así estas ansiedades que acechan a los hombres.

En efecto en este periodo entre finales del XIX y principios del XX, se produce un fenómeno de militarización de la masculinidad que se da en toda Europa. El soldado aparece como la quintaesencia de la masculinidad, modelo de género para todos los hombres, más allá del contexto bélico ${ }^{82}$. Este modelo de hombría se consolida en España también en las guerras del Rif. Para los sectores del africanismo reaccionario, el soldado se convierte en modelo de masculinidad preponderante. Inspirado en el caballero español conquistador, se basa en la dureza de un cuerpo fuerte y resistente, capaz de las máximas proezas físicas con una voluntad determinada y firme. Ha de ser capaz

78. Las bases teóricas de los estudios sobre masculinidades y en particular la noción de masculinidad hegemónica en: Connell, Raewyn; Messerschmidt, James. W: «Hegemonic Masculinity: Rethinking the Concept», Gender and Society, 19, 6, pp. 829-859, 2002 y Kimmel Michael; Connell, Raewyn; Eran John: Handbook of Studies on Men and Masculinities. Thousand Oak: Sage Publications, 2005. Para el caso concreto de España en el marco del colonialismo en Marruecos: TorRes Delgado, Gemma: "El soldat espanyol i el guerrer rifeny, a l'africanisme militar durant les guerres del Rif (1900-1927)", Segle XX, Revista Catalana d'Història, 9 , 2016, pp. 1-24, id: La virilitat d'Espanya a l'Àfrica: op. cit.

79. ARESTI Nerea: Médicos, donjuanes y mujeres modernas: los ideales de feminidad y masculinidad en el primer tercio del siglo XX. Bilbao: Universidad del País Vasco, Servicio Editorial-Euskal Herriko Unibertsitatea, 2001; id: "Masculinidad y nación en la España; de los años 1920 y 1930", Mélanges de la Casa de Velázquez, 42(2), 2012, p. 55-72; NAsh, Mary: Feminidades y masculinidades. Arquetipos y prácticas de género. Madrid: Alianza Editorial, 2014.

80. VÁzQuez, Francisco y Cleminson, Richard: Los invisibles: una historia de la homosexualidad masculina en España, 1850-1939. Granda: Comares, 2011.

81. VÁzquez, Francisco y Cleminson, Richard: op. cit.; Aresti, Nerea: Masculinidades en tela de juicio: hombre y género en el primer tercio del siglo XX. Madrid: Cátedra, 2010.

82. Dawson, Graham: Soldier Heroes: British Adventure, Empire, and the Imagining of Masculinities. London; New York: Routledge, 1994.; CAPDEvila, Luc: "L'identité masculine et les fatigues de la guerre (1914 1945)». Vingtième Siècle. Revue d'bistoire, 3,74, pp. 97-108, 2002. RoYNETTE, Odile: "La construction du masculine», Vingtième Siècle. Revue d'histoire 3,75, pp. 85-96, 2022. Mosse, George: Fallen Soldiers: Reshaping the Memory of the World Wars. New York; Oxford: Oxford University Press, 1999; Mosse, George: La imagen del hombre. La creación de la moderna masculinidad. Madrid: Talasa Ediciones, 2000. 
de soportar las máximas penalidades. Lleno de vigor y energía, especialmente agresivo y con un coraje extremo debe ser impetuoso y arrojado. Más que en la reflexión y el cálculo, se basa en la acción irracional y en el deseo por la lucha y en una extrema capacidad de sacrificio, que linda con la temeridad. La victoria, la dominación y el ejercicio del poder forman parte también de esta identidad masculina ${ }^{83}$.

La masculinidad nos ayuda a analizar cómo se performan determinadas emociones hacia la nación, ya que muchos de estos afectos que genera la patria están íntimamente ligados a la hombría. Las emociones nacionales descritas se relacionan con la activación de ideas, pensamientos y valores que tienen que ver con este modelo de género concreto, preponderante en este contexto, el soldado. El miedo a la debilidad, a perder preeminencia y autoridad, la angustia por no estar a la altura o no ser lo suficientemente fuerte, tan propio de la experiencia viril, se relaciona con la ansiedad que teñía la empresa colonial, con el sentimiento de humillación ante las derrotas y de vergüenza en la comparación con otras potencias coloniales. Sentimientos que se vinculan con una hombría militar que se define en términos de fortaleza, resistencia, victoria y también con los miedos que asediaban a los hombres, que tenían que demostrar continuamente una virilidad en duda, que podía ser fácilmente perdida o degenerada. Como hemos estudiado en otro lugar, la nación se imaginó y se caracterizó en este contexto con los atributos de la masculinidad militar. La nación debía ser, como el soldado, fuerte, vencedora y exitosa en el concierto de naciones europeas imperiales ${ }^{84}$.

Estas ansiedades propias de la experiencia de la virilidad son también experiencia de nación. Como hemos descrito, la vinculación de los hombres con esta forma de nación imperial se sostenía también en emociones como el orgullo, la soberbia o el placer de la dominación- que están también ligadas al modelo viril de masculinidad soldadesca y agresiva. Un ideal que es ampliamente difundido y conocido, por lo que también permite normalizar estas emociones como propias de la experiencia nacional ${ }^{85}$.

83. Torres Delgado, Gemma: "El soldat espanyol i el guerrer rifeny...», op. cit.; id: La virilitat d'Espanya a l'Àfrica...: op. cit.

84. Para una análisis sobre cómo los valores e imáginarios masculinos permitían representar e imaginar la nación en este contexto veáse: Torres Delgado, Gemma: «La nación viril...», op. cit.

85. Reddy ha estudiado en este mismo sentido la importancia de las emociones en el surgimiento y supervivencia de la milicia nacional en el contexto de la Revolución Francesa: «there can hardly be any doubt that, by one means or another, the precepts of sentimentalism were widely enough shared by 1792 that raw volunteers could coordinate their actions with the help of an emotional style, even though they had had virtually no training as units and little knowledge of each other. Such styles are best communicated by means of sensory-rich participatory performances: ritual, predication, theater. But they may also be conveyed, or suggested, by literature, art, music, iconography, architecture, dress». "No cabe duda de que, de una manera u otra, los preceptos del sentimentalismo fueron lo suficientemente compartidos en 1792 como para que los voluntarios pudieran coordinar sus acciones con la ayuda de este estilo emocional, a pesar de que prácticamente no habían recibido formación ni se conocían mútuamente. Dichos estilos se comunican mejor mediante actividades experienciales: rituales, predicaciones, teatro. Pero también pueden ser transmitidos 
Así se educa a los sujetos en la nación, a través de emociones como el orgullo del sacrificio por la patria, el placer de la violencia y el gusto en la humillación del otro. Los sentimientos de vergüenza y dolor por los fracasos nacionales deben evitarse y resarcirse, pero caracterizan también la relación de los sujetos con la patria. Son emociones nacionales que resultan reconocibles e íntimas porque forman parte de la experiencia de la masculinidad, de un modelo concreto el de masculinidad miliar. Estos son los componentes de género, los ideales soldadescos, que se activan en la enunciación emocional que vincula a los sujetos con la nación. Así las emociones ligadas a la virilidad permiten a los sujetos participar de la nación imperial.

\section{LAS EMOCIONES NACIONALES ANTIHEROICAS}

Desde posiciones diversas se respondió a este proyecto nacional y colonial. Las críticas más severas provenían del socialismo, el anarquismo y los sectores más radicales del catalanismo. Eran contrarios a la España conquistadora y tampoco asumieron un proyecto de España moderna y «civilizadora». Criticaron duramente la empresa marroquí. La colonización se había llevado a cabo solo en beneficio de los capitalistas para explotar las riquezas mineras del Rif y, especialmente, en interés de los militares que pretendían así aumentar su preeminencia social. Denunciaron las malas condiciones que sufrían los soldados rasos en campaña y la injusticia que suponía la guerra para las clases populares por la inequidad de los reclutamientos. La colonización en el Rif suscitó numerosas protestas, ya en 1909 el conflicto marroquí encendió las revueltas de la Semana Trágica en Barcelona. A partir de los años veinte, las protestas se intensificaron. La cuestión marroquí sirvió como catalizador de las críticas contra el auge del pensamiento reaccionario que representaba el africanismo militar ${ }^{86}$.

Diversos escritores y periodistas, que sirvieron como soldados en esta guerra, dejaron escrita su experiencia en forma de diario personal o de recreación literaria como denuncia de la guerra y la colonización. Estas obras aparecieron especialmente a partir de los años treinta. Mientras duró la guerra y la dictadura de Primo de Rivera, la censura impedía la publicación de este tipo de obras. La mayoría relatan los hechos ocurridos durante y después de la derrota de Annual. Uno de los autores más

\footnotetext{
a través de la literatura, el arte, la música, la iconografía, la arquitectura, la vestimenta». REDDY, William: op. cit, p. 331. Del mismo modo, en nuestro contexto las emociones vinculadas a la masculinidad soldadesca son fundamentales en la vivencia de la nación.

86. UCELAY DA CAL, Enric: "Els enemics dels meus enemics. Les simpaties del nacionalisme català pels 'moros': 1900-1936", L'Avenç: Revista d'bistòria i cultura, 28, 1980, pp. 29-40; MARTín CORRALEs, Eloy: "Catalunya i el Marroc, un segle i mig de relación, L'Avenç: Revista d'història i cultura, 256, 2001, pp. 18-26; MADARIAGA, María Rosa: En el barranco del lobo: las guerras de Marruecos. Madrid: Alianza Editorial, 2005; NERín, Gustau: op. cit.; BACHOUd, André: Los españoles ante las campañas de Marruecos. Madrid: Espasa-Calpe, 1988.
} 
reconocidos contra la guerra colonial fue el periodista Ramón J. Sender, miembro de la CNT-FAI y represaliado por sus actividades contra la dictadura de Primo de Rivera. Publicó su novela, Imán, en 1930, sobre su experiencia en Marruecos (entre 1922 y 1924). Tuvo una gran repercusión, se publicó una segunda edición que llegó a vender $30.000 \operatorname{copias}^{87}$. Desde el catalanismo, el escritor y periodista Prous i Vila, cercano a Estat Català, publicó, en 1934, Quatres gotes de sang. Dietari d'un català al Marroc, como resultado de su servicio en Marruecos, entre febrero de 1921 y octubre de 1922. También las novelas populares por entregas, con una difusión creciente a principios de siglo, reprodujeron este discurso crítico. Es el caso, por ejemplo, de la obra del estudiante Salvador Ferrer, titulada Uno de tantos, que se publicó en 1930. Relata la historia de un joven que es forzado a filas en 1924. Arturo Barea, miembro del partido socialista y de la UGT, también sirvió en Marruecos entre 1920 y 1923. Escribió su experiencia en La forja de un rebelde, publicada en 1943. Podemos leer en la mayoría de estos textos una reivindicación común y un discurso de denuncia compartido. Los textos mencionados respondían a los relatos dominantes sobre la colonización en Marruecos difundidos por los sectores más reaccionarios, que exaltaban los logros y virtudes del ejército, de la campaña y de la España imperial. Se contestaban explícitamente las escenas recurrentes y convencionales de exaltación heroica y patriótica que reproducían ${ }^{88}$. Estas críticas a la guerra de Marruecos no significaban que no se asumiera el marco nacional español, sino que estas obras estaban contribuyendo también a la reflexión sobre la identidad nacional en el contexto colonial ${ }^{89}$.

Esta contestación anticolonial no fue sólo discursiva, a través del lenguaje, sino que tuvo también una clara dimensión emocional. En nuestro contexto, la comunidad emocional que vivía la nación a través de los valores masculinos soldadescos era preponderante. Ahora bien, esta literatura nos muestra otra comunidad emocional, marginal en este contexto. Los diferentes autores comparten una misma experiencia y están reivindicando otras emociones como legítimas para los varones y para la relación de los individuos con la nación. En estos relatos vemos a hombres que no participan de las emociones nacionales que proponían los sectores más reaccionarios. Con ello

87. PeÑuelas, Marcelino: «Introducción». En: SENDER, Ramón J.: Imán. Barcelona: Ediciones Destino, 2003; VÁzQUEZ, Ignacio: La memoria del desastre (1921). Las principales narraciones de África como fuente bistórica, Tesis doctoral. Universidad Nacional de Educación a Distancia, 2008.

88. Sender y Díaz Fernández escriben sus obras en respuesta, concretamente, a Diario de una Bandera y al artículo publicado en la Revista de Tropas Coloniales "La maniobra" (1924), escritas por Francisco Franco para alabar al ejército español. Véase: López BARRANCO, Jose: El Rif en armas. La narrativa española sobre la guerra de Marruecos (1859-2005). Madrid: Mare Nostrum Comunicación, 2006.

89. ARCHILÉs, Ferran: «Experiencias de la nación? Nacionalización e identidades en la España restauracioncita (1898-c.1920)». En: MoRENo, J.: Construir España: nacionalismo español y procesos de nacionalización, Madrid. Centro de estudios políticos y constitucionales, 2007; id: ARCHILÉs, Ferran: «Vivir la comunidad imaginada..." op. cit. 
impugnan su proyecto de nación imperial. Podemos identificar, por tanto, otra forma de vivir la nación en nuestro contexto.

En su teorización de los regímenes emocionales, Reddy incluyó la descripción de lo que llamó sufrimiento emocional, definido como un conflicto entre diferentes objetivos o valores que provoca sufrimiento. Precisamente utiliza el ejemplo del soldado que en el instante de matar a su primer oponente siente miedo y culpa. Los valores militares y los del pacifismo o el rechazo a matar a otro ser humano entran en conflicto y se produce este sufrimiento. A través de la declaración emocional (emotive), se enuncia y se resuelve el conflicto cuando se define y se vive cuál de las dos emociones en conflicto prevalece ${ }^{90}$. Según la teorización de Reddy, los regímenes emocionales más estrictos impiden la diversidad de experiencias emocionales y esta negociación y transformación en los valores y objetivos relevantes para el sujeto (que Reddy llama navegación).

En estos contextos emocionalmente opresivos, se crean refugios emocionales en los que

norms are relaxed or even reversed; mental control efforts may be temporarily set aside. Affective connections, otherwise illicit, may be established, even celebrated. Such emotional refuges may take a great variety of forms, from private understandings, to informal sociability, to Carnival-type ritual, to international secret brotherhoods. They probably play a role in most emotional regimes. Their significance is polyvalent. They may make the current order more livable for some people, some of the time. For others, or in other times, they may provide a place from which contestation, conflict, and transformation are launched ${ }^{91}$.

Rosenwein reconoce la relevancia de la formulación de los refugios emocionales de Reddy y del sufrimiento como motor de cambio histórico ${ }^{92}$. Lo incluye en su noción de comunidades emocionales, que es menos dicotómica e implica la existencia de estos refugios emocionales o de comunidades emocionales subordinadas en todos los contextos. Así en cada contexto debemos imaginar

a large circle within which are smaller circles, none entirely concentric but rather distributed unevenly within the given space. The large circle is the overaching emotional community,

90. REDDY, William: op. cit., p. 212.

91. «Las normas se relajan o incluso se invierten; los esfuerzos de control mental pueden suspenderse temporalmente. Se pueden establecer lazos afectivos, en otro momento ilícitos, ahora se celebran. Estos refugios emocionales pueden adoptar una gran variedad de formas, desde relaciones personales, hasta la sociabilidad informal, pasando por rituales carnavalescos, hasta hermandades secretas internacionales. Probablemente juegan un papel en la mayoría de los regímenes emocionales. Su importancia es polivalente. Pueden hacer que el régimen actual sea más habitable para algunos individuos, en algunos momentos. Para otros, o en otros momentos, pueden proporcionar un lugar desde el cual se inician la contestación, el conflicto y la transformación", REDDY, William: op. cit., p. 128.

92. Rosenwein, Barbara H.: op. cit., p. 23. 
tied together by fundamental assumptions, values, goals, feeling rules, and accepted modes of expression. The smaller circles represent subordinate emotional comunities ${ }^{93}$.

Tanto la noción de comunidad emocional subordinada como la noción de refugio emocional implican la contestación del régimen emocional preponderante.

En nuestro contexto, un refugio o una comunidad emocional marginal se configura como una impugnación a las prescripciones emocionales de la nación imperial predominante. Esta impugnación se produce necesariamente a través del cuestionamiento de las emociones viriles propias de la masculinidad militar hegemónica en Marruecos. Tan importantes son las emociones que se prescriben como las que se censuran, ya que las comunidades emocionales "depend not only on the emotions that they emphasizeand how and in what contexts they do so-but also by the ones that they demote to the tangential or do not recognize at all ${ }^{94}$. Así esta impugnación se produce también en buena medida a través de la visibilización de emociones censuradas en la comunidad emocional dominante. De esta forma ambas, nación y masculinidad imperial, son subvertidas a través de la reivindicación de una vivencia emocional compartida y censurada en el ideal masculino soldadesco y patriótico: el dolor.

La alegría que caracteriza la experiencia masculina del sacrificio por la nación es un engaño según el estudiante protagonista de la novela de Ferrer. «Todo era una desconsoladora mentira" ${ }^{95}$ : los periódicos que describían a los soldados valientes y decididos, las imágenes de soldados que iban a luchar cantando himnos a la patria y con la sonrisa en los labios. El alborozo por la lucha no era la única experiencia de los soldados que participaron en las guerras marroquíes, en los relatos anticoloniales se muestra otro repertorio emocional.

En primer lugar, el dolor físico aparece en estas crónicas en cuerpos débiles, agotados, llenos de heridas y magulladuras, cuerpos que no resistían el esfuerzo: «noventa kilómetros en tres jornadas [...] Los hombros desollados por el correaje y el sudor, las plantas de los pies abiertas y la cal del camino en las grietas ${ }^{96}$. El dolor se mostraba en toda su crudeza en hombres enfermos, con fiebres altas, eczemas, temblorosos y envejecidos prematuramente ${ }^{97}$. Si el sufrimiento físico es descrito recurrentemente, el

93. «Un círculo grande dentro del cual hay círculos más pequeños, ninguno completamente concéntrico, sino más bien distribuido de manera desigual en cada contexto. El círculo grande es la comunidad emocional general, unida por presupuestos básicos, valores, metas, reglas emocionales y modos de expresión aceptados y compartidos. Los círculos más pequeños representan comunidades emocionales subordinadas", Ibid, p. 24.

94. «dependen no solo de las emociones que enfatizan, y cómo y en qué contextos lo hacen, sino también de las que relegan a los márgenes o no reconocen en absolutom, Ibid, p. 26.

95. FERrer, Salvador: Uno de tantos. Servicios de retaguardia. Barcelona: Ferrer, 1930, p. 46.

96. SENDER, Ramón J.: Imán. Barcelona: Ediciones Destino, 2003 [1930], p. 33.

97. Sender, Ramón J.: op. cit., p. 33; Prous i Vila, Josep Maria: Quatre gotes de sang. Dietari d'un català al Marroc. Reus: Edicions del Centre de Lectura Prous Science, 2003; BAREA, Arturo: La forja de un rebelde II. La ruta. Madrid: Biblioteca El Mundo, 2001. 
dolor emocional es omnipresente. Los hombres se desmoronaban ante la dureza de la campaña, por el dolor por la muerte de compañeros y también enemigos como el mismo Barea que relata cómo después de Annual, en el escenario de los hechos, tuvo que colaborar en la tarea de enterrar los cadáveres. La escena es espantosa, el olor penetrante. Después de esta experiencia no puede dormir, ni comer. Finalmente, no resiste, cae desmayado ante el sargento de guardia y se le concede un permiso. Cuando vuelve a casa no es capaz de probar la carne, vomita y cuando relata su experiencia a los familiares, explica: «me eché a llorar como un niño pequeño, más infeliz y miserable que nunca, por el daño que estaba haciendo, por el dolor que había visto»98. En estas crónicas vemos, por tanto, a hombres desesperados como el soldado que partió hacia la guerra "sollozando como lo que era, como un chiquillo»"99. También aparece el sufrimiento por la madre y la familia que queda lejos y se expresa a través del cuerpo, como hemos indicado al inicio, un elemento muy importante en la configuración de comunidades emocionales. Ferrer relata en esta escena la convulsión corporal del soldado que debe dejar a su madre cuando comparte su sufrimiento con un compañero

al poco rato cogióme la mano y febrilmente, temblándole el aliento, con voz rencorosa, dejó escapar las palabras entre los dientes [..]. Moriría de pena si no volviera y yo no quiero que muera estando lejos de mí; yo tengo que volver. Se recostó en mi hombro y empezó a llorar ${ }^{100}$.

El sufrimiento por la muerte que rodea a los soldados se acompaña de otra emoción fundamental en la experiencia de guerra: el miedo. En estos relatos vemos a hombres descompuestos por el temor por una muerte segura y próxima. En el relato de Sender, un soldado perdido en el campo marroquí, con los pies heridos, no puede huir. Su protagonista, Viance, «descubre ahora en el oficial la desesperación que apenas lograba contener y que desborda al sentirse tuteado. Suenan unos tiros lejanos y suelta a llorar en silencio» ${ }^{101}$. El miedo es una constante en Marruecos. Salvador Ferrer lo deja claro, en la guerra no hay disciplina «en la guerra solamente existe miedo insuperable a la muerte o miedo, en tono menor a la superioridad ${ }^{102}$.

Estos relatos nos muestran muy claramente el sufrimiento emocional en términos de Reddy que deriva de una contradicción entre dos sistemas emocionales, el de las emociones patrióticas heroicas y las emociones de miedo y dolor, que también aparecen en campaña. En muchas ocasiones se hace evidente cuando la emoción de coraje que

\footnotetext{
98. BAREA, Arturo: op. cit., p. 143.

99. FERRER, Salvador: op. cit., p. 22.

100. Ibid, p. 20.

101. SENDER, Ramón J.: op. cit., p. 156.

102. FERRER, Salvador: op. cit., p. 49.
} 
se quiere aparentar no se puede sostener. Ante un ataque de los rifeños un teniente al mando de un blocao proclama:

Esos mokandis — se dijo- al parecer quieren ver cuál es el temple del nuevo jefe del blocao y añadió con sorna: pues si quieren se van a enterar. Pero si hubiera podido mirarse en un espejo habría visto su cara pálida como la cera ${ }^{103}$.

El cuerpo delata al teniente que siente un miedo que no puede disimular. La contradicción entre la alegría y el placer por la lucha prescritas por el ideal patriótico y estas otras emociones vividas en el campo de batalla se convierte en el tema principal de la novela popular Los hombres son de bierro publicada en 1927. Trata sobre un joven que es enviado como soldado a Marruecos. No nos explica las aventuras guerreras del hijo, se centra en el sufrimiento de la familia, pero no el sufrimiento de la madre, que sería lo más habitual, sino en el sufrimiento del padre. Quiere aparentar seguridad en sus convicciones sobre la necesidad de que los hombres cumplan con su deber y se sacrifiquen por la nación, pero la novela nos desvela cómo sufre por su hijo. Cuando se llevan al joven para realizar el sorteo de quintos el padre «en un alarde de tranquilidad, [...] se encerró en el despacho, aparentando tranquilidad [...] era como una fiera enjaulada. Mordiendo el puro, paseaba por el despacho presa de un miedo insuperable ${ }^{104}$.Vemos a un hombre que intenta evitar el sentimiento de miedo y disimularlo y afirmar una actitud emocional heroica respecto a la nación, la que prescribe estoicismo ante la muerte por ella de los seres queridos. No lo consigue. Así esta contraposición entre diferentes formas de vivencia emocional de la nación se hace evidente. La resolución de esta contradicción con la visibilización o incluso reivindicación de emociones de debilidad, sufrimiento y miedo, que se produce cuando se enuncian, resulta en una contestación a la comunidad emocional preponderante y su vivencia de la nación imperial.

De este modo, las emociones de alegría y enardecimiento patrio que determinaban la relación de los hombres con la nación son impugnadas en estas novelas que nos hablan de otras experiencias emocionales como el dolor, el miedo y, finalmente, también la desesperación y la depresión. Frente a la exaltación emocional prescrita aparecen hombres deprimidos:

Marruecos nos ha robado la juventud y la alegría. Yo ya no podré estar alegre jamás. Cuando los embates de la vida me hagan atravesar momentos graves sentiré la desilusión de estas estancias de hoy y seré un hombre vencido ${ }^{105}$.

103. SENDER, Ramón J.: op. cit., p. 46.

104. Castro, Cristóbal de. Los hombres de bierro. Madrid: La Novela Mundial, 1927, p. 19.

105. FERRER, Salvador: op. cit., p. 214. 
Vemos también en estas crónicas a hombres, inertes, sin vida. Viance, protagonista de la novela Imán, sufre las consecuencias de la guerra: «en lugar de volver a ser el de antes se queda vacío e inánime ante la llanura, poblada de cadáveres» ${ }^{106}$. Este proceso termina con la pérdida de sentido de la existencia y el deseo de suicidio. Precisamente el final de la novela de Sender nos muestra a su protagonista que regresa a su pueblo. Desesperado por el dolor sufrido, solo siente deseos de suicidio. Es un sentimiento compartido y forma parte de la experiencia emocional relatada en muchas de estas crónicas anticoloniales, "no hay uno solo que crea en la necesidad de nada de esto". [...] ¡Es más cómodo para todos romper filas y pegarnos un tiro!»107. Salvador Ferrer explica esta experiencia íntima. Durante su estancia en Marruecos sufría muchas veces "una vaga sensación de muerte» ${ }^{108}$. El deseo de exponerse al peligro para que una bala eliminase el sufrimiento no es una excepción en el escenario de guerra «en estos momentos es imposible coordinar una sola idea. Falla el aliento ${ }^{109}$.

Finalmente, esta exaltación emocional que era tan importante en la retórica patriótica aparece descrita en estas obras como simple brutalidad. Barea describe así una arenga de Millán Astray. El teniente coronel insta a los jóvenes soldados a ser caballeros de la muerte con un cuerpo que había sufrido una "transformación histérica». Su vOz "Sollozaba, aullaba»"110. Es una figura esperpéntica, un fanático, «más horrífico que nunca, epiléptico, en una locura homicida furiosa ${ }^{111}$. Los oficiales españoles eran presentados como hombres tan agresivos que parecían dementes. La exaltación emocional no era electricidad patriótica, sino animalidad. Así frente a la alegría, el placer de la batalla, la exaltación patria como emociones que vinculan a los hombres con la nación, en estas crónicas aparece la desesperanza, el vacío, la pérdida de sentido de la existencia hasta desear la muerte. Este sistema de emociones que se hace patente, hasta se reivindica, tiene una clara connotación de género. Estos sentimientos vienen a impugnar los mandatos de la masculinidad preponderante en este contexto: la dureza, la resistencia, el valor. Todos atributos propios de un modelo de género muy concreto, el soldado.

El cuerpo es también muy relevante como hemos indicado en la experiencia de cualquier realidad política y también la nación. En esta literatura anticolonial se muestra enfermo y maltrecho, delata a los hombres que, aunque quieren aparentar valor, tienen miedo, finalmente se describen con profusión escenas de cadáveres. En los relatos más oficiales no se acostumbran a mostrar los cadáveres de los soldados. En cambio, en los anticoloniales se muestran de forma descarnada los detalles escabrosos de la muerte de

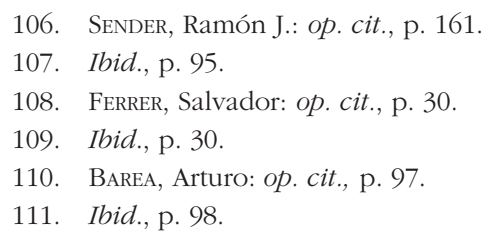


los hombres y la sordidez de las escenas de cadáveres abandonados en el campo de batalla para evidenciar así el sufrimiento y sinsentido que suponía la guerra. Prous i Vila describe los cadáveres de soldados que, buscando agua desesperadamente, murieron amarrados al suelo, intentando lamer la arena que estaba un poco fresca. Así como los cadáveres que encontraban a menudo en las montañas marroquíes

Tenen els caps aixafats, aplanats dins la terra, esmicolats, [...] altres apareixen amb els braços trencats, les cames esmicolades. Ens adonem, però, que a tots els han estat tallades o arrencades les parts ${ }^{112}$.

El dolor físico, pero también la pérdida de la dignidad que implica una muerte cruel, grotesca y sórdida como la que se describe forma parte de esta crítica al proyecto colonial. Esta se produce a través de la impugnación de las emociones de soberbia, vanidad autoritaria que caracterizaban la vivencia nacional prescrita por el africanismo reaccionario.

En efecto estas emociones de dolor, desesperación o miedo son incompatibles con el resto de las emociones nacionales heroicas: el orgullo patrio, el gusto por la dominación y la vanidad del ejercicio del poder. Frente a estas emociones aparece siempre el dolor. Es explícito en el relato de Ferrer que presenta a dos cadáveres con los genitales mutilados como los representantes de la España imperial: «era la constatación más petulante a todas nuestras petulancias ${ }^{113}$. Los cuerpos masculinos presentan una nación ridículamente autoritaria que actuaba por reaños, con pretensiones de grandeza y victoria que no podía sostener. Los relatos anticoloniales cuestionan así los afanes de grandeza propios de la retórica emocional patriótica del africanismo militar.

En otras ocasiones aparece también el ridículo. Tanto Sender como Prous i Vila explican que una vez derrotados, los oficiales se quitaban las insignias para parecer soldados rasos, pensando que así serían más benévolos con ellos los rifeños ${ }^{114}$. Un comandante, completamente mareado en el barco que trasportaba las tropas, es descrito como un «arlequín de trapo que ha perdido mucho aserrín» y que se agarra a su esposa que intenta "valientemente» que no caiga ${ }^{115}$. El orgullo, la vanidad o el honor desaparecían así del repertorio emocional de la vivencia de la nación imperial.

En este mismo sentido, el placer del ejercicio del poder y la autoridad también se ve cuestionado cuando se hace evidente que los españoles pierden su preeminencia colonial ante los rifeños, pueblo supuestamente inferior. Prous i Vila reproduce una conversación entre un español y un rifeño en la que el español extiende la piel de una ternera en el suelo para explicar que el mapa de España es como la piel de

112. Prous I Vila, Josep Maria: op. cit., p. 106.

113. Ferrer, Salvador: op. cit., p. 90.

114. Prous i Vila, Josep Maria: op. cit., p. 294.

115. Barea, Arturo: op. cit., p. 256. 
un toro, a lo que el rifeño responde con sorna: «Pues Hispania ser vaca: esto no ser piel de buey. Diu tot rient i colpejant l'espatlla de Calpe, qui se'l mira sense saber què contestar»"16. Así España pierde su dignidad nacional en estos relatos. Lo cual se expresa todavía más claramente a través de la metáfora de género en la insistencia de estos autores en reseñar anécdotas de soldados españoles que se dejaron seducir por mujeres rifeñas. En uno de los cuentos de Díaz Fernández, un soldado aislado en un blocao está dominado hasta tal punto por el deseo sexual hacia una joven rifeña que cede cuando ella le pide que abra la verja del campamento. Este gesto provoca un ataque de los rifeños y cuatro soldados españoles muertos ${ }^{117}$. Una anécdota similar se describe en otro de los relatos, protagonizado por África, la querida rifeña del teniente español, Riaño. África representa la cabila. El cuento relata cómo engaña y finalmente mata al confiado soldado español118. España era inocente y confiada, había creído que podría someter a los cabileños y finalmente se había demostrado víctima y no victoriosa, en una descomposición evidente del poder colonial. África, el Rif, no estaba dominado por los españoles, sino que era su desgracia, su muerte. A través de la inversión de poder colonial y de género se cuestiona una de las principales emociones viriles que permitían a los sujetos vivir la nación imperial: el orgullo, la soberbia de la autoridad y la dominación. De nuevo esta experiencia impugna los valores de la masculinidad soldadesca que prescriben poder, preeminencia, victoria e incluso humillación del enemigo $^{119}$.

Finalmente, la dimensión política de estas experiencias emocionales se expresa de forma explícita en los relatos. Se produce una impugnación manifiesta de la nación imperial cuando la sordidez de la guerra y el sufrimiento desautorizan las proclamas patrióticas de los soldados. Un sargento, herido de muerte en el relato de Ferrer «antes de caer de bruces prorrumpió, bélicamente, ingenuamente: ¡Viva España! [...]”, al instante ofreció un buen blanco y «un paco le levantó la tapa de los sesos!» ${ }^{120}$. El dolor y la muerte deslegitiman los vítores a la patria, que pierden así su sentido. Las exaltaciones nacionales quedan silenciadas por el dolor de los hombres.

Otro repertorio emocional emerge en las experiencias de los soldados en estas obras anticoloniales. Frente al orgullo, el placer de la dominación y la victoria, aparecen hombres que han perdido toda autoridad colonial, son ridículos. La alegría de la lucha, la exaltación emocional del sacrificio patrio desaparece. A ello se contrapone otra experiencia: el dolor, el sufrimiento físico y emocional que lleva a los hombres a la deshumanización e incluso al deseo de suicidio. Estas emociones se basan en otros

\footnotetext{
116. Prous i Vila, Josep Maria: op. cit., p. 161.

117. Díaz Fernández, José: El blocao. Madrid: Turner, 1976 [1928], p. 36.

118. Ibid.

119. Torres Delgado, Gemma: La virilitat d'Espanya a l'Àfrica..., op. cit

120. FERRER, Salvador: op. cit., p. 126.
} 
valores respecto a la masculinidad y a la patria que activan otras emociones que, en este refugio emocional, no deben ser contraladas, sino que se expresan, es más, incluso se reivindican como legítimas en la vivencia de la nación. En estas crónicas vemos, pues, otra experiencia de la nación en África que impugna el proyecto nacional reaccionario al no participar de las emociones patrióticas que lo sostienen. Emociones que eran nacionales y viriles a un tiempo ${ }^{121}$.

En efecto en estos relatos se subvierte también la masculinidad militar heroica que sostenía la experiencia de la nación imperial. Se cuestiona la dureza física y mental prescrita a los hombres por la masculinidad militar hegemónica. Vemos a varones vulnerables, débiles y que tienen miedo. No queda rastro del arrojo, el valor o la voluntad decidida por la lucha ni del soldado que es capaz de soportar las máximas penalidades, que triunfa y domina. En estas obras se cuestiona que estos valores sean los únicos posibles para vivir la masculinidad. De hecho, en la mayoría de ellos se denuncia que este modelo viril soldadesco es una farsa. Se reproduce en los discursos oficiales y en la prensa, pero ni los soldados, ni los oficiales lo cumplen ni lo pueden cumplir en el campo de batalla. En esta literatura anticolonial no se asocian en ningún momento este sufrimiento y debilidad con un fracaso, con la feminización o la emasculación, sino que se reivindican como la experiencia real de los hombres en la guerra y por tanto se prestigian como propias y legítimas de la experiencia viril ${ }^{122}$. Así en los relatos anticoloniales vemos a hombres que impugnan la nación imperial cuando subvierten la masculinidad hegemónica a través de la visibilización de las emociones de dolor y miedo. La resistencia al nacionalismo imperial reaccionario se produce a través de la legitimación de emociones masculinas censuradas, lo cual es posible en el marco de un refugio emocional o de una comunidad emocional marginal en este contexto. Como afirma Moscoso, elegir expresar o no una emoción, obedecer o ignorar las convenciones sobre las emociones correctas o legítimas en un determinado contexto debe considerarse como un acto político ${ }^{123}$. Así la experiencia de dolor de los hombres se convierte

121. Moscoco ha estudiado también de modo similar el dolor, la indignación, la locura, el miedo, el desamparo que provoca la guerra en la experiencia de un marino durante la Guerra Civil. Describe también como en alguno de sus relatos y dibujos, concretamente en los que habla de los niños como víctimas de la guerra, "la sobriedad y la valentía de la vida militar pueden reemplazarse aquí por un régimen emocional en el que se permiten ciertas expresiones. La referencia al llanto o lágrimas, por ejemplo, ausente en los episodios más crudos, parece aceptable en estos casos». Véase: Moscoso, Javier: "De la Historia de las Emociones...", op. cit., p. 226.

122. Para un análisis sobre cómo a través de esta literatura se impugna la masculinidad heroica preponderante en este contexto y cómo se reivindican otras experiencias como propias de la masculinidad véase: Torres Delgado, Gemma: "La masculinidad subversiva en las guerras coloniales de España en el Rif». En: Zabalgoitia, Mauricio: Hombres en peligro. Género, nación e imperio en la España de cambio de siglo. Frankfurt-Madrid: Iberoamericana Verveurt, Frankfurt-Madrid.

123. Moscoso, Javier: "Politics of pain...» op. cit., p. 68. 
en una protesta contra el nacionalismo reaccionario que se está consolidando entre la elite militar colonial, esta vivencia de dolor es un acto político.

En un sentido similar, Arbaiza ha estudiado el surgimiento del movimiento obrero como un acontecimiento emocional. Entre 1884 y 1890, se produce una articulación emocional de la humillación o la vergüenza que sentían los obreros ante un discurso burgués que expresaba asco respecto a sus cuerpos, concebidos como abyectos, portadores de enfermedades, sucios ${ }^{124}$. "La formación de la clase obrera o del socialismo, en sus orígenes, constituyó un acto hermenéutico de carácter afectivo o emocional por parte de quienes no tenían el poder de nombrar el mundo, una hermenéutica de los débiles» ${ }^{125}$. Como en el caso que describe Arbaiza, en esta literatura anticolonial se articula a través del cuerpo y de las emociones una subjetividad política, una comunidad emocional que impugna la vivencia imperante de la nación imperial. Este proceso tiene también una clara dimensión corporal: el dolor físico y el efecto en el cuerpo del miedo, la enfermedad y las penalidades de la guerra son fundamentales en su configuración.

\section{MasCUlinidad Y VIVENCIA EMOCIONAL DE LA NACIÓN}

En África se vive, se experimenta la nación, de forma distinta por parte de diferentes comunidades emocionales. Asistimos a un proceso de educación emocional en el que se prescriben determinadas emociones — soberbia, enardecimiento, alegría de la lucha, placer de la violencia- como necesarias para la adhesión a la patria, así vive la nación el africanismo reaccionario. Al mismo tiempo este repertorio emocional se contradice con otras emociones de los hombres vividas en el contexto bélico como el miedo y el dolor. Se muestran como emociones imposibles de disimular. Finalmente aparecen como una reivindicación a través de la cual se impugna el nacionalismo dominante. Esto es posible gracias a la configuración de una comunidad emocional subordinada o de un refugio emocional que permite enunciar y articular políticamente estas emociones. Diferentes comunidades emocionales conviven en África y representan diferentes experiencias de la nación imperial.

Hemos podido comprobar cómo la dimensión de género es fundamental en estos procesos de vivencia de la nación. Las emociones están determinadas por los valores sociales preeminentes en cada contexto, entre ellos, los de género son fundamentales. Las emociones que vinculan a los sujetos con la nación imperial se relacionan con la experiencia de la virilidad. El dolor por la humillación, la alegría y la exaltación emocional en el sacrificio por la patria o el goce de la dominación están íntimamente

124. Arbaiza, Mercedes: op. cit., p. 71.

125. Arbaiza, Mercedes: "Cuerpo, emoción y política en los orígenes de la clase obrera en España (18841890), Ayer, 98, 2, pp. 45-70, p. 48. 
relacionadas con la experiencia de la masculinidad militar heroica, que demanda a los hombres dureza física y emocional, deseo de lucha, autoridad, capacidad de sacrificio y que censura el sufrimiento masculino. Es decir, con un modelo de masculinidad muy concreto, el soldado. Al mismo tiempo, las crónicas anticoloniales muestran hombres débiles que cuestionan las emociones vinculadas a la masculinidad heroica. El dolor se contrapone a la alegría de luchar por la nación o el ridículo y la pérdida de autoridad colonial al orgullo, la vanidad o el placer de la dominación. A través de la impugnación de las emociones viriles heroicas y la visibilización de las emociones censuradas en el modelo de masculinidad soldadesco se impugna también la vivencia emocional de la nación imperial.

Todo ello no implica que las mujeres no participen en este proceso. Como hemos comprobado en una de las obras citadas como ejemplo, una mujer, Elvia, participa plenamente de la educación emocional de la nación y de todas las emociones masculinas que implica. Así las emociones viriles pasan a ser parte de una vivencia de la nación que comparten hombres y mujeres. Se convierten en un valor social común, que es reconocido, cotidiano para todos y todas. Así los individuos participan de la nación a través de algo tan íntimo, tan cotidiano como el género, como la virilidad y las emociones masculinas. A través del estudio de las emociones vinculadas a la virilidad podemos entender, por tanto, cómo los sujetos participan de la nación de forma cotidiana y experiencial. Además, hemos podido mostrar en su dimensión más íntima la estrecha vinculación entre masculinidad y nación. 